\title{
Festuca amethystina (Poaceae) w Polsce - nowe stanowiska, historia odkryć i zasięg występowania
}

\author{
MARCin KiEdRZYŃSKi, KATARZYNA M. ZiELIŃSKA \\ i JANINA JAKUBOWSKA-GABARA
}

\begin{abstract}
KiedrZyŃsKi, M., ZielińsKA, K. M. AND JAKUBowsKa-GabARA, J. 2020. Festuca amethystina (Poaceae) in Poland - new localities, history of discovery and the area of occurrence. Fragmenta Floristica et Geobotanica Polonica 27(2): 495-508. Kraków. e-ISSN 2449-8890, ISSN 1640-629X.
\end{abstract}

\begin{abstract}
Festuca amethystina L. is an interesting species for the analysis of the impact of the profoundness and areal representativeness of the field botanical research on the knowledge about the geographical range of the rare taxa. In the paper the new data on the occurrence of amethyst fescue was presented. These data complete the pattern of the species occurrence in central Poland. The second aim of the article was the analysis of the history of the localities discoveries in the whole country. The development of knowledge on this subject was very uneven. Historical processes influencing the possibility of botany development, and the number of researchers particularly interested in a given taxonomic group or habitat type, were of great importance. The third aim was the assessment if we can conclude about the real geographical range of the species under study from the current knowledge about its occurrence. The results of modelling with the Maxent algorithm were presented. We evaluate the currently known range as realistic, in accordance with the present state of knowledge there is quite a high probability of new localities discoveries, but rather not far from the limits of the known geographical range in the country.
\end{abstract}

KEY wORDS: Festuca, geographical range, history of botanical research, new localities, rare species, Species Distribution Models

M. Kiedrzyński (autor korespondencyjny), Katedra Biogeografii, Paleoekologii i Ochrony Przyrody, Wydziat Biologii i Ochrony Środowiska Uniwersytet Łódzki, ul. Banacha 1/3, 90-237 Łódź, Polska; e-mail: marcin.kiedrzynski@biol.uni.lodz.pl

K. M. Zielińska, J. Jakubowska-Gabara, Katedra Geobotaniki i Ekologii Roślin, Wydziat Biologii i Ochrony Środowiska Uniwersytet Łódzki, ul. Banacha 12/16, 90-237 Łódź, Polska; e-mail: katarzyna. zielinska@biol.uni.lodz.pl

\section{WSTĘP}

Festuca amethystina L. (kostrzewa ametystowa) występuje głównie w obrębie Alp, Gór Dynarskich, Karpat i Niżu Środkowopolskiego (MEUSEL i in. 1965; JAKUBOWSKA-GABARA 1994; KIEDRZYŃSKI i in. 2015, 2017). Gatunek reprezentuje alpijsko-środkowoeuropejski typ zasięgu i należy do europejsko-umiarkowanej grupy górskiej wyróżnianej wewnątrz europejsko umiarkowanego podelementu geograficznego (ZAJĄC \& ZAJĄC 2009). Zasięg F. amethystina 
jest porozrywany, cechuje się wieloma wyspami zasięgowymi i obecnością izolowanych stanowisk, w tym np. w greckich górach Pindos lub w północno-wschodniej Turcji. Polskie populacje kostrzewy ametystowej reprezentują północną, niżową wyspę zasięgową i uważane są za reliktowe, być może z czasów tundry plejstoceńskiej (SzAFER 1930).

Kostrzewa ametystowa należy do grupy wąskolistnych traw, które są podobne pod względem morfologii, a jednym z kluczowych elementów diagnostycznych jest anatomia przekrojów liści. Z uwagi na fakt, że zmienność tej cechy w obrębie rodzaju Festuca może być modyfikowana przez warunki środowiskowe (CONERT 1996; WILSON 1999; DĄBROWSKA 2012) identyfikacja taksonomiczna omawianego gatunku wymaga doświadczenia. Podobieństwo fizjonomiczne do innych taksonów powoduje, że prawdopodobne jest pomijanie kostrzewy ametystowej w badaniach terenowych.

W obrębie Festuca amethystina zostały wyróżnione cztery podgatunki/rasy geograficzne (MARKGRAF-Dannenberg 1980). To tradycyjne ujęcie uważane jest obecnie za dyskusyjne, wykazano potrzebę rewizji wewnętrznego zróżnicowania F. amethystina (REwICz i in. 2018). W ujęciu MARKGRAF-DANNENBERG (1980) polska część zasięgu zaliczana była do podgatunku ritschlii (JAKUBOWSKA-GABARA 1994; NoBIS \& PIWOWARCZYK 2007). Z uwagi na fakt, że podgatunek ten poza Polską podawany był jedynie z kilku stanowisk w Niemczech, uważany był dotąd za subendemiczny dla Niżu Polskiego (MireK \& PiĘKOŚ-MirkowA 2009). W literaturze pojawiła się również wzmianka o odnalezieniu na terenie naszego kraju podgatunku typowego subsp. amethystina, jednak bez dokładniejszych danych o lokalizacji stanowisk oraz informacji o zbiorach zielnikowych (PAwLus 1993). Analizę występowania $F$. amethystina na terenie naszego kraju komplikowało również jego wcześniejsze, szersze ujęcie taksonomiczne, obejmujące „odmianę tatrzańską” - Festuca amethystina L. var. tatrae Czakó (SzAFER i in. 1923), obecnie uważaną za odrębny gatunek - Festuca tatrae (Czakó) Degen, będący endemitem Karpat Zachodnich (Pogan 1977; PięKoŚ-Mirkowa i in. 1996; Mráz i in. 2016).

Festuca amethystina występuje w Polsce niemal wyłącznie w subkontynentalnych dąbrowach zespołu Potentillo albae-Quercetum (JakUBOwsKA-GABARA 1994; NoBIS \& PiwOWARCZYK 2007; KIEDRZYŃSKi i in. 2015). Subkontynentalne, mezotroficzne lasy dębowe (związek Potentillo albae-Quercion), to znane ostoje populacji reliktowych i rzadkich roślin (ROLEČEK 2007; KIEDRZYŃSKI \& JAKUBOWSKA-GABARA 2014). Te bogate gatunkowo, umiarkowanie ciepłolubne zbiorowiska, występują w specyficznych warunkach siedliskowych, ale w całej Europie Środkowej utrzymywane były również dzięki odpowiedniemu reżimowi zaburzeń antropozoogenicznych - szczególnie presji dużych roślinożerców (VERA 2000; RALSKA-JASIEWICZOWA i in. 2003; ROLEČEK 2007; JAMRICHOVÁ i in. 2012). W ciągu ostatnich dekad, po zaprzestaniu tradycyjnych form użytkowania, obserwowane jest ich ustępowanie. Ekspansja gatunków, takich jak: Carpinus betulus, Tilia cordata czy Corylus avellana powoduje zanik ,świetlistych” fitocenoz i związanych z nimi zespołów roślin i zwierząt (KwIATKOWsKA \& WyszOMIRSKI 1988; JAKUBOwSKA-GABARA 1996; HÉDL i in. 2010; KIEDRZYŃSKI i in. 2010). Jest to jeden z powodów zaniku stanowisk kostrzewy ametystowej, która we wszystkich dotychczasowych wydaniach Polskiej czerwonej księgi roślin wymieniana była wśród gatunków narażonych na wyginięcie (PAWLUS 1993; JAKUBOWSKA-GABARA 2001, 2014). Z tego względu poszukiwanie nowych stanowisk ma istotne 
znaczenie konserwatorskie. Każda nowo odkryta populacja może być ważna dla zachowania $F$. amethystina we florze naszego kraju.

Aż do lat 80. XX w. stanowiska Festuca amethystina w Polsce znane były niemal wyłącznie z terenu Wielkopolski, południowego Pomorza i Ziemi Lubuskiej (PAwLus 1993). Jednak już na początku XX w. Profesor Władysław Szafer przewidywał, że zasięg kostrzewy ametystowej na obszarach niżowych Polski może być większy (SzAFER 1919). Hipoteza ta została późnej potwierdzona (m.in. BRóż 1981; JAKUBOWSKA-GABARA 1994; NoBIS \& PiwOWARCZYK 2007), ale biorąc pod uwagę możliwość pomijania gatunku w badaniach florystycznych, pytanie o rzeczywisty jego zasięg w Polsce ciagle powraca.

Nowoczesne metody modelowania rozmieszczenia gatunków (Species Distribution Models - SDMs) oraz coraz większa dostępność przestrzennych danych środowiskowych umożliwiają predykcję miejsc, gdzie warunki sprzyjają występowaniu badanego taksonu. Modele takie są narzędziem szczególnie przydatnym do przewidywania potencjalnych miejsc występowania gatunków trudnych do identyfikacji. W ostatnim czasie zostały opublikowane wyniki modelowania dotyczące potencjalnego zasięgu Festuca amethystina na Niżu Polskim (KIEDRZYŃSKi i in. 2015, 2017), co dało możliwość porównania znanego zasięgu z tym jaki uzyskano w modelach.

Celem niniejszego artykułu jest: a) przedstawienie nowych stanowisk tego gatunku w Polsce odkrytych w latach 2011-2020, b) ustalenie chronologii odkryć kostrzewy ametystowej w Polsce oraz c) analiza stanu wiedzy na temat występowania gatunku na Niżu Polskim w świetle aktualnych wyników modelowania.

\section{MATERIAŁY I METODY}

W pracy przedstawiono szczegółowe lokalizacje 15 stanowisk Festuca amethystina odnalezionych w latach 2011-2020. Kilka z nich zostało wzmiankowanych w pracy JAKUBOWSKIEJ-GABARY (2014) jako dane niepublikowane, jednak bez podania szczegółów lokalizacji. Stanowiska uszeregowano według mezoregionów fizycznogeograficznych przyjętych za Solon i in. (2018). Podano również: położenie względem miejscowości, obszarów chronionych, lokalizację leśną, współrzędne geograficzne, numer kwadratu ATPOL (ZAJĄC \& ZAJĄC 2001) w siatce $2 \times 2 \mathrm{~km}$ oraz ogólne informacje o siedlisku. Przyporządkowanie do kwadratów w siatce ATPOL $2 \times 2 \mathrm{~km}$ podano $\mathrm{z}$ wykorzystaniem narzędzi kartograficznych $\mathrm{w}$ oprogramowaniu Arc Map 9.2 (ESRI), szablonów ze stron: http://www.komsta.net/atpol/; https://botany.pl/atpol (VEREY 2017) oraz warstwy GIS z kwadratami ATPOL utworzonej z pliku .shp dostępnego na stronie: https://botany.pl/atpol. Za odrębne stanowiska uznawano lokalizacje gatunku położone w odległości co najmniej jednego kilometra od siebie. W opisie stanowisk wykorzystano takie skróty, jak: msc. - miejscowość, kw. - kwadrat, rez. - rezerwat, PK - Park Krajobrazowy, wydz. - wydzielenie, Ur. - Uroczysko, Nadl. - Nadleśnictwo, drz - drzewostan.

W analizie chronologii odkryć kostrzewy ametystowej na obszarze Polski wykorzystano bazę danych opracowaną na potrzeby modelowania biogeograficznej niszy gatunku w Polsce (KIEDRZYŃsKI i in. 2015, 2017) aktualizowaną o nowo odkryte stanowiska. Zgromadzone w bazie daty florystyczne opierały się na opracowaniach JAKUBOwSKIEJ-GABARY $(1994,2014)$ i cytowanej tam literaturze; na rekordach bazy ATPOL (ZAJĄC \& ZAJĄC 2001, daty szczegółowe uzyskano dzięki uprzejmości prof. A. Zająca), na rekordach bazy Herbarium (ZIELIŃSKA i in. 2010) i Atlasu rozmieszczenia roślin naczyniowych w Polsce Środkowej (JAKUBOWSKA-GABARA i in. 2011b) oraz na kolejnych opracowaniach, w tym szczególnie na pracach Bróża (1981), Nobisa i PiwowarczyK (2007), PiwowarcZYK (2012), Piwowarskiego (2014) oraz ŁAZARSKIEGO (2016). Uzyskane informacje przeanalizowano, co dało możliwość wyróżnienia okresów charakteryzujących się swoistą dynamiką nowo odkrywanych stanowisk. 
Analizę rozmieszczenia obszarów cechujących się warunkami środowiskowymi, które sprzyjają występowaniu Festuca amethystina, oparto na opublikowanych wynikach modelowania niszy biogeograficznej z wykorzystaniem algorytmu Maxent, uwzględniając czynniki klimatyczne i edaficzne (KIEDRZYŃsKI i in. 2015, 2017). Nisza biogeograficzna gatunku odwzorowywana była przestrzennie w oprogramowaniu Maxent w postaci map prawdopodobieństwa występowania odpowiednich warunków środowiskowych (ELITH i in. 2011). Do analizy w ramach niniejszego artykułu wybrano obszary, w których prawdopodobieństwo wystąpienia $F$. amethystina wynosi powyżej 0,5 . Następnie dokonano generalizacji, która polegała na wyznaczeniu ogólnych granic takich obszarów (Ryc. 3). W dalszej kolejności granice te zostały ograniczone do zasięgu zespołu Potentillo albae-Quercetum ( $P a-Q)$ w Polsce według MatuszkiewICZA i KozŁowsKiej (1991). Do określenia obszarów o najwyższym prawdopodobieństwie występowania badanej kostrzewy, wykorzystano również rozmieszczenie płatów $P a-Q$ na mapie Potencjalnej roślinności naturalnej Polski (MATUsZKIEwICZ i in. 1995; wersja cyfrowa według MatUSZKIEWICZ 2008). Zgodnie $\mathrm{z}$ obecnym stanem wiedzy miejsca przyporządkowane na mapie roślinności potencjalnej w latach 90 . $\mathrm{XX}$ w. do $P a-Q$ należałoby w wielu przypadkach przyporządkować obecnie do innych typów roślinności. Najczęściej reprezentują one potencjalne siedliska lasów grądowych. Są to jednak miejsca, w których dąbrowa świetlista jako typ rzeczywistej roślinności miała lub ma (tam, gdzie się zachowała) najbardziej dogodne warunki do występowania. Z tego względu uwzględnienie wyżej wymienionej mapy potencjalnej roślinności jest przydatne w analizie areału występowania gatunków, takich jak kostrzewa ametystowa, które są przywiązane do dąbrów świetlistych.

\section{WYNIKI I DYSKUSJA}

\section{Nowe dane o występowaniu Festuca amethystina w Polsce}

\section{Kotlina Płocka}

1. 2 km na E od msc. Sędeń Duży, kw. DC9720, rez. Jastrząbek, Gostynińsko-Włocławski PK, Natura 2000 Uroczyska Łąckie; wydz. 103a, Nadl. Łąck, 52²9'53"N , 19³6'50"E; las dębowy z elementami dąbrowy kwaśnej i świetlistej; przy drodze leśnej i w głębi lasu, M. Kiedrzyński, 20.09.2012; kostrzewa ametystowa jest nowym składnikiem flory dla rez. Jastrząbek; znane wcześniej (1991 r.) stanowisko w rejonie Podgórza-Leśniczówki, położone jest ok. 2 km na SE (JAKUBOWSKA-GABARA 1994).

\section{Wzniesienia Łódzkie}

2. $1 \mathrm{~km}$ na SE od Łagiewnik, kw. DD6631, Las Łagiewnicki w Łodzi, PK Wzniesień Łódzkich, wydz. 10r, Leśnictwo Miejskie Łódź, 5150'33"N, 19²8'59"E; zdegenerowana dąbrowa świetlista; M. Kiedrzyński, 2012; 1,5 km na NE od stanowisk znanych z rejonu rez. Las Łagiewnicki (JAKUBOWSKA-GABARA 1994; WiTOSŁAWSKI i in. 2001).

3. $0,7 \mathrm{~km}$ na S od msc. Skotniki, kw. DD6632, Las Łagiewnicki w Łodzi, Ur. Skotniki, PK Wzniesień Łódzkich, wydz. 5f, Leśnictwo Miejskie Łódź, 51 51'4"N, 19²9’45"E; dąbrowa świetlista; M. Kiedrzyński, 2012. Stanowiska w Lesie Łagiewnickim są obecnie jedynymi potwierdzonymi w PK Wzniesień Łódzkich.

4. 1,2 km na W od msc. Węgrzynowice-Modrzewie, kw. DD8902; wydz. 54c, 29c,

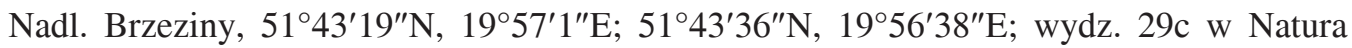
2000 Dąbrowy Świetliste k. Redzenia; dąbrowa świetlista z elementami dąbrowy kwaśnej; M. Kiedrzyński, 15.10.2016 i 02.09.2019; 1 km na S od stanowiska w Rewicy Królewskiej (JAKUBOWSKA-GABARA i in. 2011a). 


\section{Równina Piotrkowska}

5. 2,5 km na NE od osady Konewka, kw. ED9130; rez. Konewka, Spalski PK, Natura 2000 Lasy Spalskie; wydz. 153j, Nadl. Spała, 51 $34^{\prime} 29^{\prime \prime}$ N, $20^{\circ} 10^{\prime} 12^{\prime \prime}$; dąbrowa świetlista; M. Kiedrzyński, 28.09.2014; kostrzewa ametystowa jest nowym gatunkiem dla flory Spalskiego PK.

\section{Równina Radomska}

6. 2,4 km na N od msc. Ulów, Natura 2000 Dolina Dolnej Pilicy; kw. ED9424; wydz. 77a; Nadl. Grójec, $51^{\circ} 35^{\prime} 10^{\prime \prime} \mathrm{N}, 20^{\circ} 42^{\prime} 14^{\prime \prime} \mathrm{E}$; dąbrowa świetlista z udziałem Melittis melissophyllum, Hypericum montanum, Carex montana, Platanthera bifolia; M. Kiedrzyński, 28.08.2014.

\section{Wysoczyzna Bełchatowska}

7. 2 km na W od msc. Dylów Szlachecki k. Pajęczna; kw. DE4212; wydz. 84b, Ur. Siemkowice, Nadl. Wieluń, 51 ${ }^{\circ} 9^{\prime} 33^{\prime \prime} \mathrm{N}, 18^{\circ} 56^{\prime} 17^{\prime \prime} \mathrm{E}$; 35-letni drz. sosnowo-dębowy z elementami flory ciepłolubnej; w sąsiedztwie w dąbrowie świetlistej, stwierdzono m.in. Potentilla alba, Melittis melisophyllum, Epipactis helleborine, Ranunculus polyanthemos; M. Kiedrzyński \& M. Kurzac, 06.10.2014; występuje tu również największe w woj. łódzkim stanowisko Cephalanthera rubra (KIEDRZYŃSKI \& STEFANIAK 2012).

\section{Kotlina Szczercowska}

8. $4 \mathrm{~km}$ na $\mathrm{W}$ od msc. Kluki, przy przysiółku Osina, na S od drogi krajowej; kw.

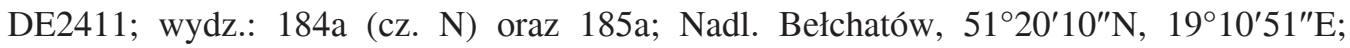
dąbrowa świetlista z udziałem Platanthera chlorantha, Trifolium lupinaster, Melittis melisophyllum i Lilium martagon; M. Kiedrzyński, 05.07.2014.

9. 2 km na SW od msc. Kamień, ok. 250 m na W od zabudowań osady Dębina, kw. DE3411; dawne Ur. Wola Wydrzyna, oddz. 154, Nadl. Bełchatów, 51 ${ }^{\circ} 14^{\prime} 54^{\prime \prime} \mathrm{N}, 19^{\circ} 11^{\prime} 14^{\prime \prime} \mathrm{E}$; drz. sosnowo-dębowy z udziałem Cephalantehra rubra, Platanthera chlorantha, Melittis melissophyllum i Digitalis grandiflora; M. Kiedrzyński, 22.06.2013; stanowisko najprawdopodobniej przestanie istnieć $\mathrm{w}$ związku z zajmowaniem powierzchni na obsługę kopalni węgla brunatnego.

\section{Wyżyna Wieluńska}

10. 1,5 km na SE od msc. Niżankowice; rez. Dąbrowa w Niżankowicach; kw. DE4123; Załęczański PK; Natura 2000 Załęczański Łuk Warty; wydz. 145a, 142b, 139g; Nadl. Wieluń, $51^{\circ} 8^{\prime} 28^{\prime \prime} \mathrm{N}, 18^{\circ} 48^{\prime 2} 22^{\prime \prime E}$; dąbrowa świetlista i kwaśna; M. Kiedrzyński \& M. Kurzac, 09.07.2013; ogólna informacja o występowaniu kostrzewy ametystowej w rez. Dąbrowa w Niżankowicach podana była również przez OlaczKa (2013). Stanowisko jest jedynym znanym w granicach Załęczańskiego PK.

\section{Wzgórza Radomszczańskie}

11. 1,2 km na W od msc. Wola Kotkowska, kw. DE4720, E część kompleksu leśnego między Gertrudowem, Waglinem a Wolą Kotkowską, lasy prywatne, $51^{\circ} 9^{\prime} 16^{\prime \prime} \mathrm{N}$, $19^{\circ} 35^{\prime} 47^{\prime \prime} \mathrm{E}$; zniekształcony las grądowy z jodłą i bukiem, we florze elementy ciepłolubne, np. Melittis melisophyllum; M. Kiedrzyński \& J. K. Kurowski, 17.07.2013. 


\section{Wzgórza Opoczyńskie}

12. 1 km na N od msc. Bukowiec nad Pilica, przy parkingu leśnym; Sulejowski PK; kw. EE1010; wydz. 19a, Nadl. Smardzewice, 51 ${ }^{\circ} 25^{\prime} 57^{\prime \prime} \mathrm{N}, 2^{\circ} 01^{\prime} 26^{\prime \prime} \mathrm{E}$; zarastająca dąbrowa świetlista; M. Kiedrzyński, 11.05.2013; jest to drugie znane stanowisko w Sulejowskim PK, gdzie gatunek jest na granicy wymarcia - kategoria CR (KUROWSKI i in. 2006).

\section{Pasmo Przedborsko-Małogoskie}

13. $1,5 \mathrm{~km}$ na SE od msc. Miejskie Pola, Przedborski PK; kw. DE5912, wydz. 124h oraz 127a, Nadl. Przedbórz, 51 ${ }^{\circ} 4^{\prime} 13^{\prime \prime} \mathrm{N}, 1^{\circ} 55^{\prime} 41^{\prime \prime} \mathrm{E}$; dąbrowa świetlista z drz. sosnowo-brzozowo-dębowym; M. Kiedrzyński, 19.08.2011; lokalna ostoja gatunków ciepłolubnych z Actaea europaea (KIEDRZYŃSKi i in. 2016), Digitalis grandiflora, Potentilla alba, Primula veris, Melittis melissophyllum i in.; kostrzewa ametystowa jest nowym składnikiem flory Przedborskiego PK.

14. 0,8 km na NE od msc. Policzko, Przedborski PK; kw. DE5922, wydz. 145f, Nadl. Przedbórz, 51 ${ }^{\circ} 3^{\prime 2} 28^{\prime \prime} \mathrm{N}, 19^{\circ} 56^{\prime} 16^{\prime \prime} \mathrm{E}$; dąbrowa świetlista z drz. sosnowo-modrzewiowo-dębowym; M. Kiedrzyński, 22.05.2020.

15. 1,8 km na NW od msc. Choiny, Góra Wilkomija, kw. EE8233, Chęcińsko-Kielecki PK, Natura 2000 Wzgórza Chęcińsko-Kieleckie, Nadl. Jędrzejów. Arkusz zielnikowy Herbarium Universitatis Lodziensis LOD155780: leg. J. Jakubowska-Gabara, 28.07.1994. Występowanie Festuca amethystina ze Wzgórz Wilkomijskich podał ostatnio ŁAZARSKI (2016), zatem odnaleziony arkusz zielnikowy z 1994 r. dodatkowo potwierdza występowanie tego gatunku w dąbrowie świetlistej na Górze Wilkomija k. Chęcin.

\section{Chronologia odkryć stanowisk Festuca amethystina w Polsce}

Dynamikę liczby znanych stanowisk Festuca amethystina stwierdzonych z obszaru Polski od roku 1850 do roku 2016 zaprezentowano na rycinie 1 . Z zestawienia tego wynika, że przyrost liczby dat florystycznych tego gatunku postępował nierównomiernie.

Pierwsze informacje o występowaniu Festuca amethystina z terenu obecnej Polski pochodzą z 1850 r. i zostały udokumentowane w materiałach zielnikowych przez G. Ritschla, który opracowywał florę Wielkiego Księstwa Poznańskiego (niem. Großherzogtum Posen) - autonomicznego terytorium wchodzącego w skład Królestwa Prus. Notowanie pochodzi z Dziewiczej Góry k. Poznania (RITSCHL 1850). Kolejne zaczęły się pojawiać dopiero po ponad 40 latach - od roku 1895. Należą do nich m.in. stanowiska znalezione na Pojezierzu Poznańskim i Gnieźnieńskim (PfuHL 1896; Bock 1908).

W latach 1885-1908 odnotowano 14 nowych dat florystycznych Festuca amethystina z tego terenu (okres II na rycinie 1). Po I wojnie światowej zaczęły pojawiać się dane o nowych stanowiskach $F$. amethystina w Wielkopolsce autorstwa polskich botaników m.in. J. Paczoskiego (materiały Uniwersytetu im. Adama Mickiewicza w Poznaniu, Herbarium POZ, JAKUBOWSKA-GABARA 1994). Jednak aż do lat 80. XX w. liczba nowo odkrytych lokalizacji była bardzo niewielka (okres III na rycinie 1), co można tłumaczyć: a) burzliwymi wydarzeniami historycznymi w początkowej i środkowej części tego okresu, b) słabym rozpoznaniem florystycznym Polski Środkowej, c) problemami z rozpoznawaniem okazów gatunku w badaniach 


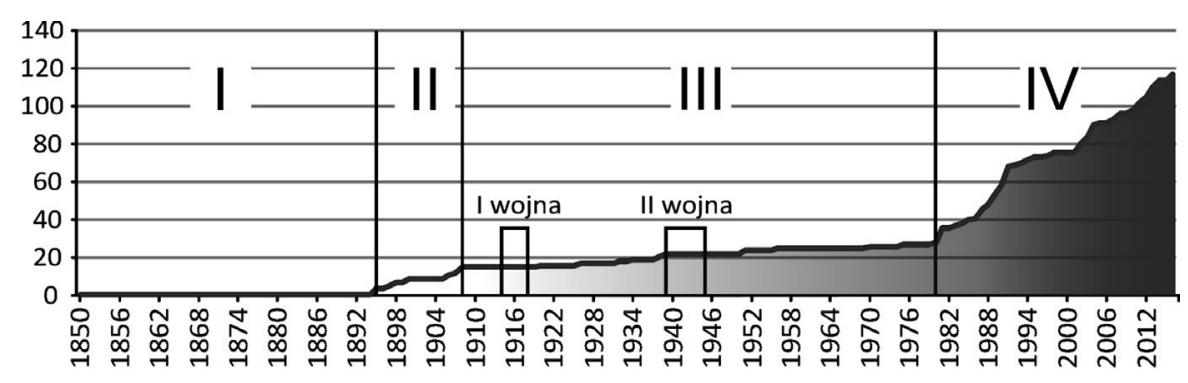

Ryc. 1. Liczba stanowisk Festuca amethystina znanych na obszarze Polski w latach 1850-2020

Fig. 1. The number of localities of Festuca amethystina known in Poland over the period 1850-2020

terenowych. W okresie tym odnaleziono jednak kilka stanowisk ważnych z biogeograficznego punktu widzenia, np.: stanowiska Łysy Młyn w południowej Wielkopolsce (SZULCZEWSKI 1951) oraz Trębaczew na Mazowszu (coll. Jakubowska-Gabara 1970, LOD; JAKUBOwSKAGABARA 1994), które rozszerzyły dotychczasowy zasięg gatunku w kierunku południowowschodnim, natomiast odkrycie stanowiska w rejonie Bielinka (coll. Kowal 1956, KRAM; JAKUBOWSKA-GABARA 1994) rozszerzyło znany zasięg na północny-zachód.

Wyraźny postęp w odkrywaniu stanowisk Festuca amethystina w Polsce nastąpił po 1980 r. i trwa do dzisiaj (okres IV na rycinie 1). Stało się tak przede wszystkim dzięki badaniom J. Jakubowskiej-Gabary oraz E. Bróża, które rozszerzyły znany zasięg występowania $F$. amethystina w naszym kraju o nowo odkryte stanowiska w Polsce Środkowej i w Górach Świętokrzyskich. W latach 90. XX w. stwierdzono również nowe stanowiska w Wielkopolsce (Wojterska 1991-1997, baza danych ATPOL). Był to okres zwiększonego wysiłku polskich botaników w związku z opracowywaniem Atlasu rozmieszczenia roślin naczyniowych $w$ Polsce (ZAJĄC \& ZAJĄC 2001), jednak jak się wydaje znaczenie miały też zainteresowania badawcze konkretnych osób, bowiem nie każdy botanik specjalizował się w rozpoznawaniu wąskolistnych kostrzew. Kolejne lata przyniosły odkrycia, które przesunęły wschodnią granicę znanego występowania kostrzewy ametystowej niemal do linii Wisły (NoBIS \& PIWOWARCZYK 2007) oraz uszczegółowiły obraz rozmieszczenia gatunku w Wielkopolsce (Chmiel 2007-2011 dane niepublikowane za JAKUBOWSKA-GABARA 2014).

Nowe stanowiska przedstawione w niniejszej pracy uzupełniają wiedzę o występowaniu gatunku w Polsce Środkowej oraz precyzują przebieg południowej granicy zasięgu w naszym kraju (np. rez. Dąbrowa w Niżankowicach i inne stanowiska na granicy nizin środkowopolskich i wyżyn).

Obecnie znany areał niżowej wyspy zasięgowej Festuca amethystina w Polsce jest zatem dużo większy niż można było przypuszczać w połowie XX w. Jego krańcowe stanowiska to Bielinek (coll. Kowal 1956, KRAM; JAKUBOWSKA-GABARA 1994) oraz Rąice (stanowisko z 1989 R. podane przez Ćwiklińskiego do ATPOL) na zachodzie, Tryszczyn k. Bydgoszczy na północy (Bock 1908 za JaKubowsKa-Gabara 1994), Ur. Chrusty k. Książa Wielkiego na południu (JAKUBOWSKA-GABARA 1994) i Kozienice (JAKUBOWSKA-GABARA 1994) oraz Borowiec i Krzemionki Opatowskie (NoBIS \& PiwowarczYK 2007) na wschodzie.

Łączna liczba stanowisk, z jakich podawana była Festuca amethystina w Polsce, wynosi 118 (Ryc. 2), niestety wiele z nich może być obecnie uznanych za historyczne 


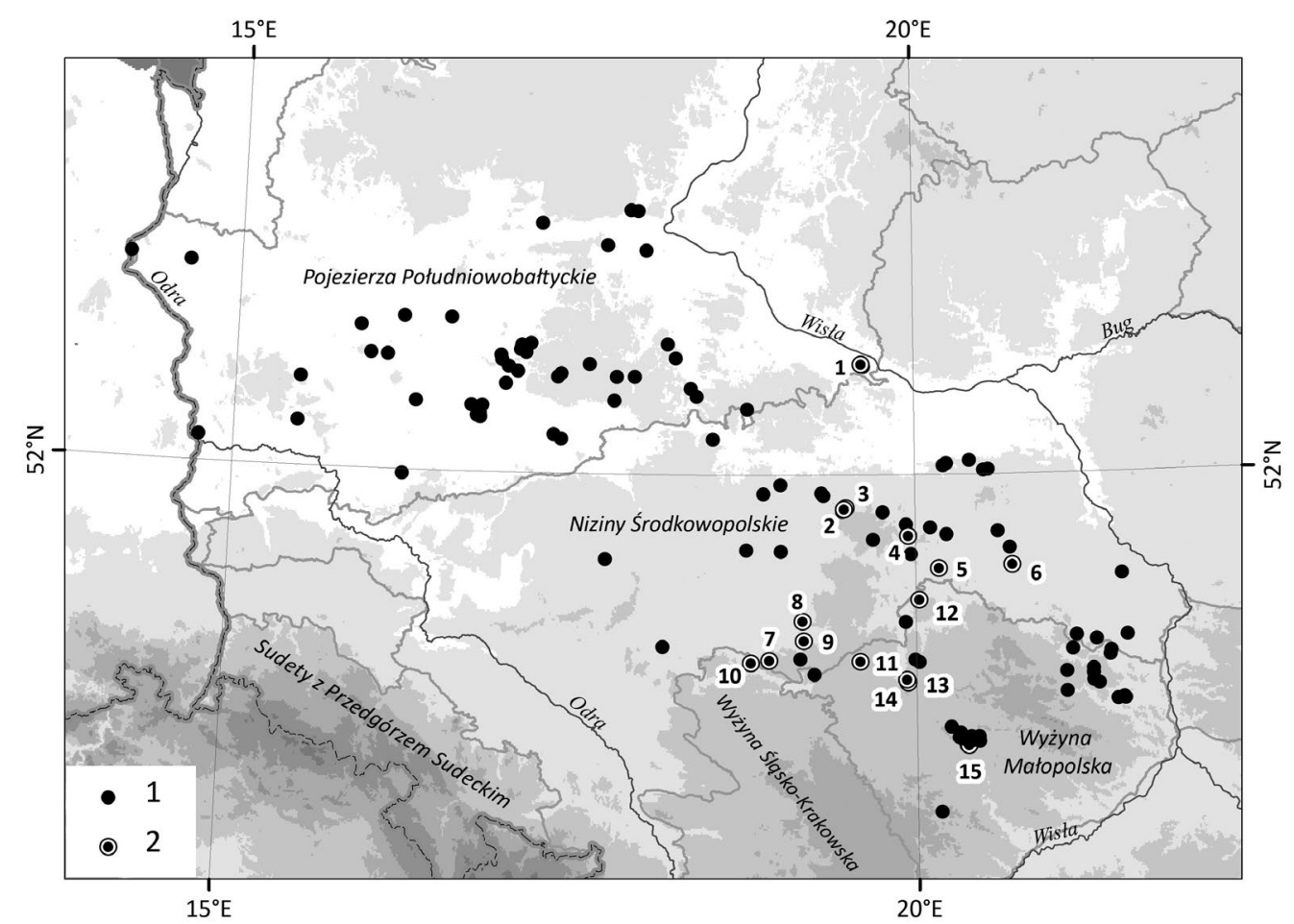

Ryc. 2. Występowanie Festuca amethystina w Polsce: 1 - znane stanowisko; 2 - nowe stanowisko z numerem zgodnym z tekstem. Granice podprowincji fizycznogeograficznych według SolON i in. (2018)

Fig. 2. The occurrence of Festuca amethystina in Poland: 1 - known locality; 2 - new locality with the following number according to text. The boundaries of physiographic provinces according to Solon et al. (2018)

(JAKUBOwSKA-GabaRA 2014 oraz mat. npbl. autorów). Dotyczy to szczególnie stanowisk położonych w obrębie pojezierzy, a więc regionów, z których badany gatunek został podany po raz pierwszy z terenu naszego kraju.

\section{Rzeczywisty a potencjalny zasięg Festuca amethystina w Polsce}

Stanowiska Festuca amethystina koncentrują się w centralnej i zachodniej części zasięgu zespołu Potentillo albae-Quercetum w Polsce, ale jednocześnie nie przekraczają granic tego zasięgu (Ryc. 3). Według wyników modelowania biogeograficznego przeprowadzonego w oparciu o dotychczas znane stanowiska, obszar występowania gatunku jest dobrze charakteryzowany przez warunki klimatyczne i edaficzne (KIEDRZYŃSKI i in. 2015). W związku z tym prawdopodobieństwo znacznego rozszerzenia dotychczas znanego zasięgu przez kolejne odkrycia stanowisk wydaje się dość niskie, z wyjątkiem południowej części Wyżyny Małopolskiej, Wyżyny Lubelsko-Lwowskiej i Wołyńsko-Podolskiej, które znalazły się w granicach obszaru o prawdopodobieństwie występowania $F$. amethystina $\mathrm{P}>0,5$ (obszaru zaznaczonego przerywaną linią na rycinie 3). Jednakże ewentualna obecność $F$. amethystina w tych regionach może być ograniczona przez pokrywy lessowe, których występowanie jest odwrotnie skorelowane z obecnością gatunku (KIEDRZYŃSKI 
i in. 2015). Na obecne występowanie $F$. amethystina mogła wpłynąć również lokalizacja refugiów glacjalnych, historia migracji i zdolności dyspersji gatunku. Wskazane elementy analizy biogeograficznej powinny być przedmiotem dalszych badań.

We wschodniej części kraju, w granicach zasięgu dąbrów świetlistych, nie udało się do tej pory odnaleźć Festuca amethystina. Według modelowania Maxent regiony te znalazły się w dużej części poza zasięgiem obszarów najbardziej odpowiednich dla gatunku (Ryc. 3). Można tutaj wskazać na dwie możliwe przyczyny takiego wyniku analiz. Po pierwsze, jak już podano wyżej, zasięg kostrzewy ametystowej może być ograniczany przez inne czynniki niż występowanie samych dąbrów świetlistych. W analizach wykazano zbieżność wschodniej granicy zasięgu gatunku ze współwystępowaniem niższych temperatur i niższych opadów w najsuchszym kwartale roku (okres zimowy) w porównaniu do obszarów, gdzie badany gatunek był stwierdzany (KIEDRZYŃSKI i in. 2015). Szczególnie istotny wydaje się efekt relatywnie niskich temperatur notowanych zimą we wschodniej Polsce,

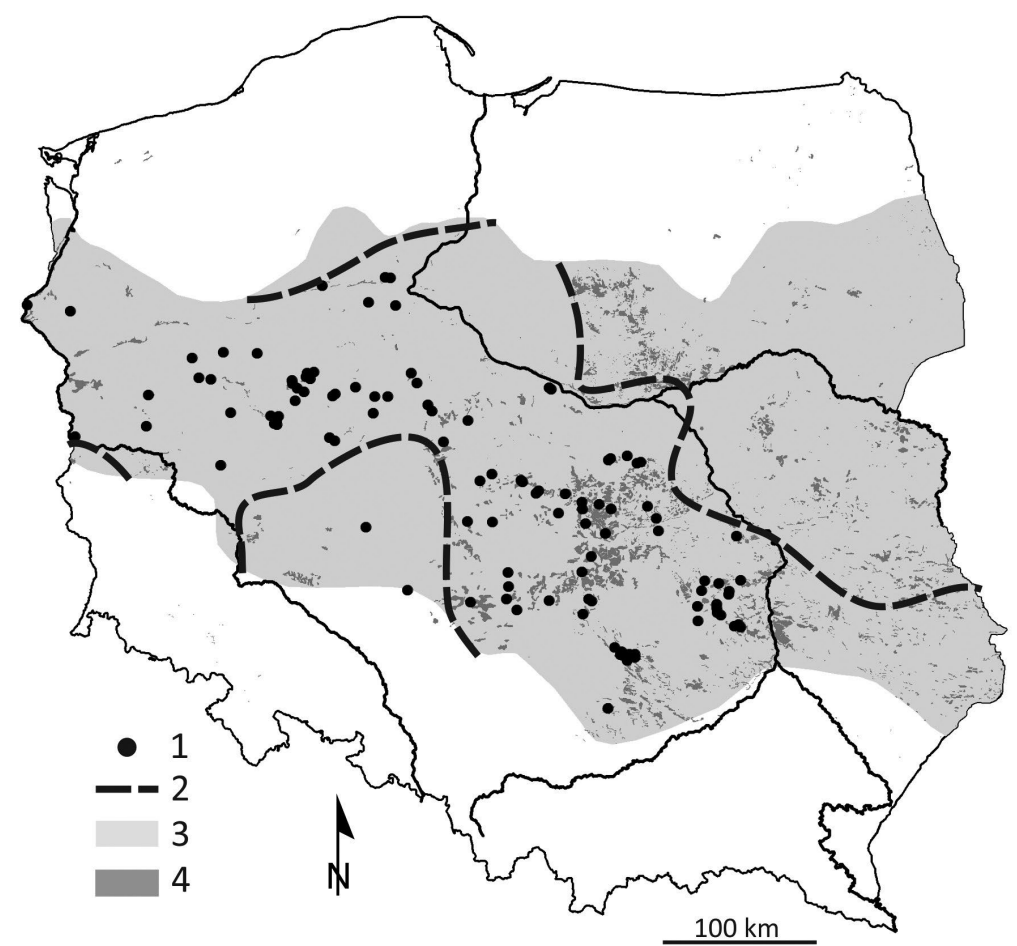

Ryc. 3. Rozmieszczenie Festuca amethystina na tle zasięgu zespołu Potentillo albae-Quercetum (Pa-Q) w Polsce: 1 - stanowiska $F$. amethystina; 2 - zasięg obszarów predystynowanych dla Festuca amethystina (prawdopodobieństwo $>0,5)$ według modelowania Maxent za KIEDRZYŃSKIM i in. (2015, 2017); 3 - zasięg $P a-Q$ wg. MatusZKIEwICZA \& KozŁowsKies (1991); 4 - płaty $P a-Q$ na mapie potencjalnej roślinności według MATUSZKIEwICZA i in. (1995) oraz MATUSZKIEWICZA (2008)

Fig. 3. Distribution of Festuca amethystina on the background of the range of association Potentillo albae-Quercetum $(P a-Q)$ in Poland: 1 - localities of $F$. amethystina; 2 - range of areas particularly predestined for $F$. amethystina (probability occurrence $\mathrm{P}>0.5)$ in the Maxent modelling according in KIEDRZYŃSKI et al. $(2015,2017) ; 3$ - the range of $P a-Q$ according to MATUSZKIEWICZ \& KozŁOWSKA 1991; 4 - patches of $P a-Q$ in the map of potential vegetation according to MATUSZKIEWICZ et al. (1995) and MATUSZKIEWICZ (2008) 
przy opadach porównywalnych do zachodniej części kraju. Może to prowadzić do konkluzji, że wzrastająca w kierunku wschodnim kontynentalizacja klimatu nie sprzyja występowaniu $F$. amethystina, pomimo obecności tam dąbrów świetlistych.

Po drugie, jak wykazano, jakość modeli zależy od liczby i rozmieszczenia uwzględnionych dat florystycznych (KIEDRZYŃSKI i in. 2017). Nowe stanowiska, szczególnie rozszerzające dotychczas znany zasięg, mają istotne znaczenie dla wyników modelowania. Trudno wskazać w modelowaniu te regiony, w których gatunek nie został dotąd stwierdzony, jeśli ich charakterystyka przyrodnicza jest odmienna od regionów, z których jest on znany. Predykcja potencjalnych miejsc występowania może zostać poprawiona poprzez zastosowanie odpowiednich technik korekcyjnych. Wyniki takich analiz w odniesieniu do Festuca amethystina zaprezentowano w pracy KIEDRZYŃSKIEGO i in. (2017). Korekty zastosowane w tym opracowaniu obejmowały m.in. ,przerzedzenie przestrzenne stanowisk” oraz dodatkowe predyktory siedliskowe, np. zagęszczenie gatunków charakterystycznych dla $P a-Q$. Jednakże żadna z zastosowanych technik nie dała wyniku, w którym potencjalnie sprzyjające obszary do występowania kostrzewy ametystowej, znacznie wykraczałyby, we wschodniej części kraju, poza obraz jaki uzyskano bez tych korekt. Wynik modelowania zaprezentowany na rycinie 3 wydaje się więc realistyczny, oczywiście przy obecnym stanie wiedzy. Rozwój technik modelowania i dostępność dokładniejszych danych środowiskowych z pewnością podniesie precyzję modeli w przyszłości.

Syntetyczna mapa zaprezentowana w niniejszym artykule (Ryc. 3) wskazuje regiony i miejsca potencjalnie najbardziej odpowiednie dla występowania Festuca amethystina w Polsce. Spodziewać się można, że w najbliższym czasie kolejne stanowiska $F$. amethystina będą odkrywane raczej w sąsiedztwie już znanych lokalizacji.

\section{PodsumowANIE}

Wiedza dotycząca zasięgu geograficznego gatunków trudnych do identyfikacji zależy ściśle od intensywności i dokładności badań florystycznych. Ma to znaczenie zwłaszcza w przypadku gatunków, które z natury występują rzadko. Festuca amethystina jest gatunkiem o cechach utrudniających odróżnienie jej od taksonów pokrewnych, stan wiedzy o jej rozmieszczeniu jest związany z pracami stosunkowo niewielkiej liczby specjalistów zainteresowanych daną grupą taksonomiczną lub określonym typem roślinności.

Na zmieniający się obraz znanego zasięgu Festuca amethystina w Polsce miały wpływ również czynniki historyczno-społeczne, w szczególności zróżnicowany rozwój badań botanicznych w poszczególnych regionach, zahamowanie lub utrudniony rozwój nauk środowiskowych w okresach wojen i w powojennych okresach odbudowy kraju. W efekcie, do lat 80. XX znajomość występowania gatunku w obecnych granicach Polski opierała się na przestrzennie niepełnym zbiorze dat florystycznych.

Analiza zaprezentowana w pracy wskazuje, że współcześnie znane granice niżowej wyspy zasięgowej Festuca amethystina w Polsce są prawdopodobnie zbliżone do stanu faktycznego. Wykazano, że dobrą metodą umożliwiającą taką ocenę jest zastosowanie modelowania rozmieszczenia obszarów potencjalnie sprzyjających danemu gatunkowi na podstawie predyktorów klimatycznych i siedliskowych. Potencjalne granice 
występowania $F$. amethystina w Polsce dają się w przekonujący sposób interpretować jako wypadkowa cech klimatu, podłoża geologicznego oraz występowania dąbrów świetlistych.

Zaprezentowane w artykule, nowo odkryte stanowiska na obszarze środkowej Polski uszczegóławiają wiedzę o obecności Festuca amethystina w tym regionie. W dwóch przypadkach potwierdzono stanowiska podane niezależnie również przez innych autorów. $\mathrm{W}$ jednym z nich stało się to za sprawą odnalezienia arkusza zielnikowego w Herbarium Universitatis Lodziensis (LOD) z lat 90. XX w.

Biorąc pod uwagę ograniczone możliwości dyspersji i powszechny zanik dąbrów świetlistych w Polsce można stwierdzić, że znalezienie nowych stanowisk Festuca amethystina, które byłyby znacznie oddalone od granic obecnie znanego jej zasięgu, jest raczej mało prawdopodobne. Nie można tego jednak całkowicie wykluczyć biorąc pod uwagę bardzo rozproszony ogólny zasięg omawianego gatunku.

\section{LITERATURA}

Bock W. 1908. Taschenflora von Bromberg (Netzegebiet). s. 214. Bromberg.

BRÓż E. 1981. Notatki florystyczne z Gór Świętokrzyskich. Cz. II. - Fragmenta Floritica et Geobotanica 27(3): 321.

Conert H. J. 1996. Festuca L. - W: G. Hegi (red.), Illustrierte Flora von Mittel-Europa. 1(3), s. 1-561. Blackwell, Berlin - Hamburg.

DĄBROWSKA A. 2012. Morpho-anatomical structure of the leaves of Festuca trachyphylla (Hack.) Krajina in the ecological aspect. - Modern Phytomorphology 1: 19-22.

Elith J., Phillips S. J., Hastie T., Dudík M., Chee Y. E. \& Yates C. J. 2011. A statistical explanation of MaxEnt for ecologists. - Diversity and Distributions 17: 43-57.

HÉDL R., KoPeCKÝ M. \& KoMÁREK J. 2010. Half a century of succession in a temperate oakwood: from species-rich community to mesic forest. - Diversity and Distributions 16: 267-276.

JakUbowska-Gabara J. 1994. Distribution of Festuca amethystina L. subsp. ritschlii (Hackel) Lemke ex Markgr.- Dannenb. in Poland. - Acta Societatis Botanicorum Poloniae 63(1): 87-95.

Jakubowska-Gabara J. 1996. Decline of Potentillo albae-Quercetum Libb. 1933 phytocoenoses in Poland. - Vegetatio 124: 45-59.

JAKUBOWSKA-GABARA J. 2001. Festuca amethystina L. Kostrzewa ametystowa. - W: R. KAŹMIERCZAKOwA \& K. ZARZYCKI (red.), Polska czerwona księga roślin. Paprotniki i rośliny kwiatowe, s. 436-438. Instytut Botaniki im. W. Szafera PAN, Instytut Ochrony Przyrody PAN, Kraków.

JaKUbowska-Gabara J. 2014. Festuca amethystina L. Kostrzewa ametystowa. - W: R. KAźmiercZaKowa, K. ZARZYCKi \& Z. MireK (red.), Polska czerwona księga roślin. Paprotniki i rośliny naczyniowe, s. 616-618. Instytut Ochrony Przyrody PAN, Kraków.

JakUbowska-Gabara J., Kucharski L., KiedrZyŃski M., WitosŁawski P., ZielińsKa K., KoŁodZiejek J., GrZYL A. \& PoPKIEwICZ P. 2011a. Nowe stanowiska rzadkich, chronionych i zagrożonych gatunków roślin naczyniowych w Polsce środkowej. - Fragmenta Floritica et Geobotanica Polonica 18(1): 29-38.

Jakubowska-Gabara J., Kucharski L., Zielińska K., KoŁodziejek J., WitosŁawski P. \& Popkiewicz P. 2011b. Atlas rozmieszczenia roślin naczyniowych w Polsce Środkowej. Gatunki chronione, rzadkie, ginące i narażone. s. 283. Wydawnictwo Uniwersytetu Łódzkiego, Łódź.

Jamrichová E., Szabó P., Hédl R., Kuneš P., Bobek P. \& Pelánkova B. 2012. Continuity and change in the vegetation of a Central European oakwood. - The Holocene 23: 46-56. 
KiedRZYŃSKi M. \& JAKUBOwSKA-GABARA J. 2014. The detection of thermophilous forest hotspots in Poland using geostatistical interpolation of plant richness. - Acta Societatis Botanicorum Poloniae 83(3): 183-189.

KiedRzyński M. \& STEFANiAK A. 2012. Cephalanthera rubra (L.) L.C. Rich. buławnik czerwony. - W: R. OlaCzeK (red.), Czerwona księga roślin województwa łódzkiego. Zagrożone rośliny naczyniowe. Zagrożone zbiorowiska roślinne, s. 296. Ogród Botaniczny w Łodzi, Uniwersytet Łódzki, Łódź.

Kiedrzyński M., JakubowsKa-Gabara J. \& KuRowski J. K. 2010. Ciepłolubne dąbrowy (Quercetalia pubescenti-petraeae). - W: W. Mróz (red.), Monitoring siedlisk przyrodniczych. Przewodnik metodyczny. Część I, s. 253-269. Główny Inspektorat Ochrony Środowiska, Warszawa.

KiedrzyŃski M., Kurowski J. K., Kiedrzyńska E. \& MaCieJewski P. 2016. Exceptionally tall individuals in a relict population of Actaea europaea (Schipcz.) J. Compton against the species of the EuroAsiatic Cimicifuga Section. - Polish Journal of Environmental Studies 25(2): 889-893.

KiedrzyŃski M., ZielińsKa K. M., KiedRZYŃsKa E. \& JAKUbowsKA-GABARA J. 2015. Regional climate and geology affecting habitat availability for a relict plant in a plain landscape: the case of Festuca amethystina L. in Poland. - Plant Ecology \& Diversity 8(3): 331-341.

KiedrZYŃSKi M., ZielińsKa K. M., RewicZ A. \& KiedRZYŃSKa E. 2017. Habitat and spatial thinning improve the Maxent models performed with incomplete data. - Journal of Geophysical Research: Biogeosciences 122: 1359-1370.

Kurowski J. K., WitosŁawski P., AndRzeJewski H. \& KiedrZYŃski M. 2006. Lista ginących i zagrożonych gatunków roślin naczyniowych Sulejowskiego Parku Krajobrazowego. - Przyroda Polski Środkowej 8: 4-17.

Kwiatkowska A. J. \& Wyszomirski T. 1988. Decline of Potentillo albae-Quercetum phytocoenoses associated with the invasion of Carpinus betulus. - Vegetatio 75: 49-55.

ŁAZARSKI G. 2016. Festuca amethystina (Poaceae) - nowy gatunek dla flory Płaskowyżu Jędrzejowskiego. - Fragmenta Floritica et Geobotanica Polonica 23(2): 370-374.

Markgraf-Dannenberg I. 1980. Festuca L. - W: T. G. Tutin, V. H. Heywood, N. A. Burges, D. M. Moore, D. H. Valentine, S. M. Walters \& D. A. Webb (red.), Flora Europaea. 5. Alismataceae to Orchidaceae (Monocotyledons), s. 125-153. Cambridge University Press, Cambridge.

Matuszkiewicz J. M. 2008. Potential natural vegetation of Poland. Instytut Geografii i Przestrzennego Zagospodarowania PAN, Warszawa. https://www.igipz.pan.pl/Roslinnosc-potencjalna-zgik.html (dostęp: 30.11.2020).

Matuszkiewicz J. M. \& KozŁowsKa A. B. 1991. Przegląd fitosocjologiczny zbiorowisk leśnych Polski ciepłolubne dąbrowy. - Fragmenta Floristica et Geobotanica 36: 203-256.

Matuszkiewicz W., Faliński J. B., Kostrowicki A. S., Matuszkiewicz J. M., Olaczek R. \& WojterSKI T. 1995. Potencjalna roślinność naturalna Polski. Mapa przeglądowa 1:300 000. Arkusze 1-12. IGiPZ PAN, Warszawa.

Meusel H., JäGER E. \& WeineRT E. 1965. Vergleichende Chorologie der zentraleuropäischen Flora. 1: 1-2. G. Fischer, Jena.

Mirek Z. \& PięKoś-Mirkowa H. 2009. Fitogeograficzne aspekty endemizmu w Polsce. - Wiadomości Botaniczne 53: 7-30.

Mráz P., Barabas D., Lengyelova L., Turis P., Schmotzer A., Janisova M. \& Ronikier M. 2016. Vascular plant endemism in the Western Carpathians: relation to geography, environmental factors and taxon traits. - Biological Journal of the Linnean Society 119: 630-648.

Nobis M. \& PiwowarczyK R. 2007. Distribution and habitat preferences of Festuca amethystina subsp. ritschlii (Poaceae) on the eastern distribution limit. - W: L. FREY (red.), Biological issues in grasses, s. 37-47. W. Szafer Institute of Botany, Polish Academy of Sciences, Kraków. 
OlaCZeK R. 2013. Rezerwaty. Ochrona przyrody w lasach Regionalnej Dyrekcji Lasów Państwowych i województwa łódzkiego. s. 183. Oficyna Wydawnicza FOREST, Józefów.

Pawlus M. 1993. Festuca amethystina L. - W: K. ZARZYCKI \& R. KAźMIERCZAKOwA (red.), Polska czerwona księga roślin, s. 212-213. Instytut Botaniki im. W. Szafera, Kraków.

PfuHL F. 1896. Die bisher in der Provinz Posen nachgewiesenen Gefässpflanzen. - Zeitschrift der Botanischer Abteilung Naturwissenschaftlicher Verein der Provinz Posen 3(1): 1-70.

Pięroś-Mirkowa H., Mirek Z. \& Miechówka A. 1996. Endemic vascular plants in the Polish Tatra Mts. Distribution and ecology. - Polish Botanical Studies 12: 1-107.

PIWOWARCZYK R. 2012. Revised distribution and plant communities of Orobanche alsatica and notes on the Orobanchaceae series Alsaticae in Poland. - Biodiversity: Research and Conservation 26: 39-51.

PIwowarski B. 2014. Rośliny naczyniowe Płaskowyżu Jędrzejowskiego (Wyżyna Małopolska). - Zeszyty Naukowe Uniwersytetu Jagiellońskiego, Prace Botaniczne 46: 1-316.

Pogan E. 1977. Kariologia flory polskiej. - W: W. SzAFER \& K. ZARZYCKI (red.), Szata roślinna Polski, s. 207-232. Państwowe Wydawnictwo Naukowe, Warszawa.

Ralska-Jasiewiczowa M., Nalepka D. \& Goslar T. 2003. Some problems of forest transformation at the transition to the oligocratic/Homo sapiens phase of Holocene interglacial in northern lowlands of central Europe. - Vegetation History and Archaeobotany 12(4): 233-247.

Rewicz A., Tomczyk P. P., KiedrzyŃski M., Zielińska K. M., JęDRZeJCZyK I., Rewers M., KiedrzyŃSKA E. \& REWICZ T. 2018. Morphometric traits in the fine-leaved fescues depend on ploidy level: the case of Festuca amethystina L. - PeerJ 6: e5576.

Ritschl G. 1850. Flora des Grossherzogthums Posen. s. 291. Druck und Verlag von E. S. Mittler Und Sohn, Berlin.

ROLEČEK J. 2007. Formalized classification of thermophilous oak forests in the Czech Republic: what brings the Cocktail method? - Preslia 79: 1-21.

Solon J., Borzyszkowski J., BidŁasik M., Richling A., Badora K., Balon J., BrzezińsKa-WóJCik T., Chabudziński Ł., Dobrowolski R., Grzegorczyk I., JodŁowski M., Kistowski M., Kot R., Krąż P., Lechnio J., Macias A., Majchrowska A., Malinowska E., Migoń P., Myga-Piątek U., Nita J., Papińska E., Rodzik J., StrzyŻ M., TerpiŁowski S. \& Ziaja W. 2018. Physico-geographical mesoregions of Poland: Verification and adjustment of boundaries on the basis of contemporary spatial data. - Geographia Polonica 91(2): 143-170.

SzAFER W. 1919. Festuca. - W: M. RACibORSKi \& W. SzAFer (red.), Flora polska. 1, s. 329-340. Akademia Umiejętności, Kraków.

SzAFER W. 1930. Element górski we florze niżu polskiego. - Rozprawy Wydziału Matematyczno-Przyrodniczego, Polska Akademia Umiejętności 69, Seria III 29, Dział B 3: 1-112.

Szafer W., PawŁowski B. \& KulCZYŇSKi S. 1923. Die Pflanzenassoziationen des Tatra Gebirges I. Die Pflanzenassoziationen des Chocholowska - Tales. - Bulletin international de l'Académie des sciences de Cracovie, Sciences naturelles, Ser. B: 1-66.

SzUlczewski J. W. 1951. Wykaz roślin naczyniowych w Wielkopolsce dotąd stwierdzonych. - Prace Komisji Biologicznej, Poznańskie Towarzystwo Przyjaciół Nauk 12(6): 1-128.

Vera F. W. M. 2000. Grazing ecology and forest history. s. 506. CABI Publishing, Oxfordshire.

VEREY M. 2017. Teoretyczna analiza i praktyczne konsekwencje przyjęcia modelowej siatki ATPOL jako odwzorowania stożkowego definiującego konwersję współrzędnych płaskich na elipsoidę WGS 84. - Fragmenta Floristica et Geobotanica Polonica 24(2): 469-488.

WiLSON B. L. 1999. Fescue taxonomy in the Pacific coast states. Mskr. pracy doktorskiej. s. 204. Oregon State University. https://ir.library.oregonstate.edu/concern/graduate_thesis_or_dissertations/xg94hs97t?locale=en (dostęp: 30.11.2020). 
WitosŁawski P., ANDRZeJewski H. \& KuRowski J. K. 2001. Atlas rozmieszczenia roślin naczyniowych Lasu Łagiewnickiego. - W: J. K. KUROwsKi (red.), Szata roślinna Lasu Łagiewnickiego w Łodzi, s. 23-96. Urząd Miasta Łodzi, Uniwersytet Łódzki, Łódź.

ZAJĄC A. \& ZAJĄC M. (red.). 2001. Atlas rozmieszczenia roślin naczyniowych w Polsce. s. xii + 715. Nakładem Pracownii Chorologii Komputerowej Instytutu Botaniki Uniwersytetu Jagiellońskiego, Kraków.

ZAJĄC M. \& ZAJĄC A. 2009. The geographical elements of native flora of Poland. s. 94. Institute of Botany, Jagiellonian University, Kraków.

Zielińska K., JaKubowska-Gabara J. \& KoŁodZiejeK J. 2010. Adaptation of the "Herbarium" computer database to archiving and analysis of floristic data. - Acta Universitatis Lodziensis, Folia Biologica et Oecologica 6: 145-150.

\section{SUMMARY}

Knowledge about the geographical range of the rare and difficult in recognition species strictly depends on the profoundness and areal representativeness of floristic research conducted in the analysed area. In the article new data on Festuca amethystina occurrence was presented. We depicted thirteen new localities, one specification of previous general information, and one information about herbarium sheet from 1994 that confirms recently noted by other authors. The total number of the known localities in Poland is 118 .

On the example of Festuca amethystina we can observe how historical events affect the knowledge of the geographic range of the taxon. During the times of partitions of Poland in XIX century, only from the German part of the country localities of $F$. amethystina were known (Poznań and Gniezno Lakelands). Throughout the history of the development of botanical research, the number of known localities grew unevenly, and new discoveries did not indicate the actual geographical range of the species till the end of $\mathrm{XX}$ century and the beginning of this century.

The question is to what extent can be convinced that the currently known range is realistic. The assumption was made that the good method allowing to assess to what extent the known geographic range of this type of taxa corresponds to its actual area of the occurrence is the use of mathematical modelling of distribution of favourable for the species sites (SDMs - Species Distribution Models). In the modelling the climatic, edaphic, and biotic data (based on the occurrence of plant communities and the group of species typical of communities in which the analysed taxon is present) should be used. The consistency of the state of knowledge with the facts is indicated by such a modelling result, which makes it possible to explain the limits of the range by the variability of climate features, soils or the occurrence of plant communities being habitats for the examined plant. Festuca amethystina is a interesting species for such analysis. The assessment of the credibility of the currently known range of the analysed taxon was made by analysing the results of modelling presented in detail in the previous authors' publications (KIEDRZYŃSKI et al. 2015, 2017). It used climatic and edaphic data as well as knowledge about the range of the subcontinental oak forest, Potentillo albae-Quercetum (MATUSZKIEwICZ \& KozŁowsKa 1991) and the distribution of this forest association on the Map of Potential Natural Vegetation of Poland (MATUszKIEwICZ et al. 1995; MATUSZKIEWICZ 2008). It has been shown that it is highly probable that the currently known geographical range of $F$. amethystina in Poland can be regarded as close to the truth. According to the presented analysis, one can expect to discover new localities of amethyst fescue in Poland, but the probability that they will be far from the limits of the currently known range is limited.

Wptynęto: 03.10.2020 r.; przyjęto do druku: 16.12.2020 r. 